\title{
Loss of the $\mathrm{EP}_{2}$ Prostaglandin $\mathrm{E}_{2}$ Receptor in Immortalized Human Keratinocytes Results in Increased Invasiveness and Decreased Paxillin Expression
}

Raymond L. Konger, ${ }^{*}$ Glynis A. Scott, ${ }^{\dagger}$ Yvonne Landt, ${ }^{\ddagger}$ Jack H. Ladenson, ${ }^{\ddagger}$ and Alice P. Pentland ${ }^{\dagger}$

From the Department of Pathology and Laboratory Medicine," Indiana University School of Medicine, Indianapolis, Indiana; the Department of Dermatology, ${ }^{\dagger}$ University of Rochester School of Medicine and Dentistry, Rochester, New York; and the Division of Laboratory Medicine, ${ }^{\ddagger}$ Washington University School of Medicine, Saint Louis, Missouri

Prostaglandin $\mathrm{E}_{2}\left(\mathrm{PGE}_{2}\right)$ receptor subtype $\mathrm{EP}_{2}$, which is coupled to cAMP metabolism, is known to mediate proliferation of primary human keratinocytes in vitro. The effect of gain or loss of $\mathrm{EP}_{2}$ receptors in immortalized human keratinocytes (HaCat cells) was examined. HaCat keratinocytes were transfected with sense or anti-sense constructs of the $\mathrm{EP}_{2}$ receptor. Loss or gain of $\mathbf{E P}_{2}$ expression was documented by immunoblot and associated changes in agonist-stimulated CAMP production. Loss or gain of $\mathbf{E P}_{2}$ receptor expression correlated with alterations in plating efficiencies but with modest affects on growth. When cell lines were studied in an organ culture model, antisense clones were highly invasive compared with vector controls and sense transfectants. A marked increase in prostaglandin production is commonly seen in malignant lesions. Because prostaglandin receptors are known to undergo ligand-induced receptor down-regulation, we sought to determine whether $\mathbf{E P}_{2}$ receptor down-regulation results in increased invasiveness. In vector controls, invasiveness was reproduced by ligand-dependent $\mathbf{E P}_{2}$ receptor downregulation as assessed by immunohistochemistry. In addition, loss of $\mathrm{EP}_{2}$ receptor expression was associated with decreased paxillin expression, a critical component of focal adhesion assembly. Thus, downregulation of $\mathrm{EP}_{2}$ receptors represents a potential mechanism for neoplastic progression to an invasive phenotype. (Am J Patbol 2002, 161:2065-2078)

Prostaglandins are lipid hormones produced in response to numerous growth factors and environmental stimuli. Synthesis of prostaglandins is dependent on two cyclo- oxygenase enzymes (COX-1 and COX-2). COX-1 is generally constitutively expressed, whereas COX-2 is induced by various mitogens, hormones, and environmental stimuli. ${ }^{1}$ Many studies show increased COX-2 expression in human epithelial malignancies, including squamous cell carcinoma. $^{2-10}$ Epidemiological and pharmacological studies demonstrate that cyclooxygenase inhibitors exhibit chemopreventive activity for various malignancies, including skin cancer. ${ }^{1,11-13}$ A direct role for COX-2 in tumorigenesis was recently demonstrated in transgenic mice with targeted overexpression of COX-2 in breast epithelium. ${ }^{14}$

There is considerable evidence that $\mathrm{PGE}_{2}$ acts to promote tumor growth secondary to its mitogenic activity, proangiogenic activity, and inhibition of apoptosis. ${ }^{1,13,15}$ However, the lack of a distinct receptor-based mechanism has frustrated past attempts to demonstrate a clear causative role for $\mathrm{PGE}_{2}$ in tumorigenesis. Four separate $\mathrm{PGE}_{2}$ receptors coupled to activation of heterotrimeric GTP-binding proteins (G-proteins) have been identified, termed $E P_{1-4}{ }^{16} \mathrm{EP}_{2}$ and $\mathrm{EP}_{4}$ receptors are known to be coupled to activation of adenylate cyclase. We have previously shown that growth of primary adult human keratinocytes (PHKs) is stimulated by activation of $\mathrm{EP}_{2}$ receptors and subsequent production of cyclic AMP. ${ }^{17}$ In mouse models of premalignant adenoma and aberrant crypt foci formation, $\mathrm{PGE}_{2}$ appears to mediate growth and angiogenesis within benign lesions via stimulation of prostaglandin receptors $\mathrm{EP}_{1}, \mathrm{EP}_{2}$, and $\mathrm{EP}_{4} \cdot{ }^{18-21}$

Invasion and metastasis represent the final step to malignant conversion. COX-2 expression and $\mathrm{PGE}_{2}$ production generally increases as lesions progress from normal to benign lesions to frank malignancy. 2,3,6,22 In both human breast cancer and non-small cell lung cancer, metastatic lesions of the lymph node exhibit markedly higher COX-2 expression or $\mathrm{PGE}_{2}$ production compared with matched

Supported by a fellowship from the Wilmot Cancer Research Foundation, a Frances Pascher Research Grant from the Dermatology Foundation, and grants from the National Institutes of Health (1-K08-AR02150-01A1, 5-R01-AR40574, and 1-R01-AR46828).

Accepted for publication August 21, 2002.

Address reprint requests to Raymond Konger, M.D., Department of Pathology and Laboratory Medicine, Indiana University School of Medicine, 406 Fesler Hall, 1120 South Dr., Indianapolis, IN 46202. E-mail: rkonger@iupui.edu. 
primary tumors. ${ }^{23,24}$ COX-2 expression has also been shown to correlate with invasiveness of various malignancies. $^{2,4,6,10,25}$ Moreover, elevated COX-2 expression correlates with a poor prognosis in several malignancies. ${ }^{5,7-9}$ The importance of elevated COX-2 in malignant progression is further suggested by the ability of cyclooxygenase inhibitors to inhibit experimental tumor metastases and invasiveness. ${ }^{26-29}$

Prostaglandin receptors, like other G-protein-coupled receptors, are known to undergo ligand-dependent down-regulation, both in vitro and in vivo. ${ }^{30-34}$ Several reports have demonstrated decreased radiolabeled $P G E_{2}$-binding sites by Scatchard analysis in human and rat breast cancer cell lines and hepatocellular carcinoma. ${ }^{35-37}$ This decreased receptor binding activity led Li and colleagues ${ }^{33}$ to propose that the increased prostaglandin production in malignancy might result in prostaglandin receptor down-regulation. Thus, ligand-dependent receptor down-regulation might represent a possible mechanism for the effects of $\mathrm{PGE}_{2}$ in malignant progression.

The ability of malignant cells to invade and migrate through the subepithelial matrix is coupled to alterations in adhesion molecules regulating focal contacts with matrix components. ${ }^{38}$ One component of focal adhesion complexes is the protein paxillin, which serves as a scaffolding protein mediating focal adhesion assembly after matrix-integrin coupling. ${ }^{39}$ Decreased paxillin expression is observed in mouse keratinocytes after malignant conversion. ${ }^{38}$ The importance of paxillin in neoplastic transformation is suggested by the ability of a number of oncogenes, such as BCR/ABL, v-src, v-crk, Ret, and papilloma virus E6 to bind directly to paxillin. ${ }^{40,41}$ Moreover, the transforming ability of the E6 oncoprotein is dependent on its ability to bind to paxillin. ${ }^{42}$ In the current work, we have examined the role of the $\mathrm{EP}_{2}$ subtype of $P G E_{2}$ receptor on features of malignant progression such as invasiveness and paxillin expression using an immortalized human keratinocyte cell line.

\section{Materials and Methods}

\section{Materials}

Butaprost and 11-deoxy $\mathrm{PGE}_{1}$ were obtained from Cayman Chemical (Ann Arbor, MI). 3-Isobutyl-1-methylxanthine and indomethacin were obtained from Sigma Chemical (St. Louis, MO). Tissue culture media, sterile phosphate-buffered saline (PBS), protein molecular weight markers, and geneticin were obtained from Life Technologies, Inc. (Gaithersburg, MD). Fetal bovine serum was obtained from BioWhittaker (Walkersville, MD). Restriction enzymes were obtained from Promega Corporation (Madison, WI). Radionucleotides, sheep antimouse IgG-F $\left(a b^{\prime}\right)_{2}$-horseradish peroxidase conjugate and Hybond ECL nitrocellulose membranes were obtained from Amersham Pharmacia Biotech (Piscataway, $\mathrm{NJ}$ ). $\mathrm{EP}_{2}$ receptor cDNA (Hup-4) was the kind gift of Dr. J. W. Regan (University of Arizona Health Sciences Center, Tucson, AZ). The pMirb plasmid was the generous gift of Dr. D. W. Ornitz (Washington University School of Medicine, St. Louis, MO). HaCat cells were obtained from Dr. N. E. Fusenig (German Cancer Research Center, Heidelberg, Germany). COS-7 and U-937 cells were obtained from the American Type Culture Collection (Gaithersburg, MD).

\section{Cell Culture}

Dermal fibroblasts were isolated from human dermis and cultured as described. ${ }^{43} \mathrm{HaCat}$ and COS-7 cells were grown on tissue culture plastic in Dulbecco's modified Eagle medium containing 10\% fetal bovine serum, 100 $\mathrm{U} / \mathrm{ml}$ penicillin, $100 \mu \mathrm{g} / \mathrm{ml}$ streptomycin, and $25 \mathrm{mmol} / \mathrm{L}$ HEPES buffer ( $N$-[2-hydroxyethyl] piperazine- $N$ '-[2-ethanesulfonic acid]). U-937 cells were grown in RPMI 1640 media containing 10\% fetal bovine serum, $100 \mathrm{U} / \mathrm{ml}$ penicillin, and $100 \mu \mathrm{g} / \mathrm{ml}$ streptomycin.

\section{Growth Assays and Plating Efficiencies}

Growth assays were performed by plating 10,000 to 20,000 cells/well into 12-well plates. After washing the monolayer once with PBS, attached cells were trypsinized and counted on days 1 and 4 using a Coulter Counter model Zf (Coulter Corp., Hialeah, FL). For plating efficiencies, both nonattached and attached cells were counted after overnight incubation. The media containing nonattached cells was first removed and placed in the counting vial. The monolayer was then washed twice with $1 \mathrm{ml}$ of PBS, and the wash buffers were pooled with the media for cell counting. Attached cells were then counted after trypsinization of the monolayer.

\section{Monoclonal Anti-Human EP 2 Receptor Antibody (Clone 2B4)}

Human $\mathrm{EP}_{2}$ receptor amino terminal peptide (MGNASNDSQSEDCETRQ) was synthesized by the Washington University Protein Chemistry Laboratory (St. Louis, MO), both as free peptide and as a tetravalent multiple antigenic peptide $\left(E P_{2}-\mathrm{MAP}\right)$. This amino terminal region of the $\mathrm{EP}_{2}$ receptor contains negligible amino acid sequence homology with other prostanoid receptor subtypes or other mammalian proteins based on a BLAST search of the National Center for Biotechnology Information database. Primary and booster immunizations with $\mathrm{EP}_{2}$-MAP were done by intraperitoneal injection into female $\mathrm{A} / \mathrm{J}$ mice. After three booster injections, high titer mice were sacrificed, spleens harvested, and hybridomas isolated by the Washington University Hybridoma Center (St. Louis, MO). Mouse serum and hybridoma supernatant titers were screened using an $\mathrm{EP}_{2}-\mathrm{MAP}$ and $E_{2}$-free peptide enzyme immunoassay (EIA) (see below). Hybridoma clone 2B4 was selected for its high activity against both $\mathrm{EP}_{2}$-MAP peptide and $\mathrm{EP}_{2}$-free peptide by EIA. Protein A column-purified ascites fluid containing the IgG2a- $\kappa$ antibody (clone 2B4) was used for immunoblotting. 


\section{Anti-Peptide EIA}

Specificity of the anti-EP $P_{2}$ monoclonal antibody for the $\mathrm{EP}_{2}$ amino terminal sequence was demonstrated by EIA. The EIA was done using both $\mathrm{EP}_{2}-\mathrm{MAP}$ immunogen and free $\mathrm{EP}_{2}$ amino terminal peptide. An $\mathrm{EP}_{3}-\mathrm{MAP}$ peptide, consisting of the first 20 amino acids of the human $\mathrm{EP}_{3}$ receptor coupled to a multiple antigen peptide core structure, and the corresponding free peptide were included as negative controls to rule out nonspecific antibody binding with either the MAP core or unrelated peptide. Five $\mu \mathrm{g}$ of peptide in $200 \mu \mathrm{l}$ of $0.125 \mathrm{~mol} / \mathrm{L}$ borate, $\mathrm{pH} 8.3$, containing $0.15 \mathrm{~mol} / \mathrm{L} \mathrm{NaCl}$ (BBS) were added to triplicate wells of a 96-well EIA plate (Costar; Corning Inc., Corning, NY). Blank wells received BBS alone. After incubating the plates at $37^{\circ} \mathrm{C}$ for 90 minutes, the contents were tapped out, and $200 \mu \mathrm{l}$ of blocking buffer (20 $\mathrm{mmol} / \mathrm{L}$ Tris, $\mathrm{pH} 7.2,0.15 \mathrm{~mol} / \mathrm{L} \mathrm{NaCl}$ (TBS) containing 1 $\mathrm{mg} / \mathrm{ml}$ BSA) added. The plates were incubated for 1 hour at $37^{\circ} \mathrm{C}$, and washed three times with TBS containing $0.05 \%$ Tween 20 (TBST). Hybridoma supernatant from clone 2B4, diluted $1: 2$ in blocking buffer containing $0.1 \%$ Tween 20 (BBT), was then added. After a 2-hour incubation at $37^{\circ} \mathrm{C}$, the wells were washed four times with TBST. Goat anti-mouse IgG-alkaline phosphatase conjugate (Sigma), diluted 1:1000 in BBT, was then added. After incubation for 1 hour at $37^{\circ} \mathrm{C}$, the wells were washed four times with TBST, and the substrate $p$-nitrophenyl phosphate (Sigma) was added $(0.67 \mathrm{mg} / \mathrm{ml}$ in $10 \%$ diethanolamine, $\mathrm{pH} 9.8$, with $0.5 \mathrm{mmol} / \mathrm{L} \mathrm{MgCl}_{2}$ ). After incubating the plates for 1 hour at $37^{\circ} \mathrm{C}$, the reaction was stopped by adding $50 \mu \mathrm{l}$ of $1 \mathrm{~mol} / \mathrm{L} \mathrm{NaOH}$. The reaction was quantitated by measuring absorbance at $420 \mathrm{~nm}$. Specific absorbance values were obtained after subtracting the absorbance measurements for blank wells (no peptide antigen added).

\section{Northern Hybridization}

Total RNA preparation, oligo-dT enrichment for poly $(A)+$ RNA, probe preparation, and hybridization were done as previously described. ${ }^{17}$

\section{RNase Protection Assay}

Total RNA was isolated from PHKs, U-937 human monocytic cells, and HaCat cells. U-937 cells were used as a positive control cell line because these cells express high levels of $\mathrm{EP}_{3}$ receptor mRNA. ${ }^{32} \mathrm{An} \mathrm{EP}_{3}$ anti-sense riboprobe was prepared by first ligating a 416-bp human $\mathrm{EP}_{3}$ receptor polymerase chain reaction fragment into the vector pCRII using the TA cloning kit (Invitrogen Corp., Carlsbad, CA). The polymerase chain reaction fragment was obtained using previously described primer pairs and cycling conditions. ${ }^{17}$ The $\mathrm{EP}_{3}$-pCRII plasmid was treated with two separate restriction enzymes BamHI/ $K p n l$ to ensure complete linearization. After agarose gel electrophoresis, the linearized band was purified for use as the riboprobe template. Glyceraldehyde 3-phosphate dehydrogenase (GAPDH) riboprobes were prepared us- ing the pTRI-GAPDH-human plasmid vector (Ambion Inc., Austin, TX). Probes were synthesized using [ $\left.{ }^{32} \mathrm{P}\right]$ UTP and band-purified from denaturing polyacrylamide gels using an RNase Protection Assay II kit per the manufacturer's instructions (Ambion, Inc.). Hybridization was done using kit buffers for 20 hours at $42^{\circ} \mathrm{C}$. Hybridized probe:RNA was then digested with RNase $A / T 1$, diluted to $1: 100$, for 30 minutes at $37^{\circ} \mathrm{C}$. After electrophoretic separation of samples on a $6 \%$ nondenaturing polyacrylamide gel, bands were detected using a phosphorimager (Molecular Dynamics, Sunnyvale, CA).

\section{Plasmids and Transfections}

The pMirb plasmid is a mammalian expression vector that utilizes a Maloney murine leukemia virus long terminal repeat promoter and an encephalomyocarditis virus internal ribosome entry site to produce a bicystronic transcript. A neomycin phosphotransferase gene product is present downstream of the internal ribosome entry site sequence. A 1125-bp Dral fragment of the $\mathrm{EP}_{2}$ receptor open reading frame (bp 124 to 1248) was cut out of the Hup-4 plasmid. ${ }^{44}$ This fragment was then ligated into the pMirb plasmid at a Spel site upstream of the internal ribosome entry site site. Clones were isolated that contained the $\mathrm{EP}_{2}$ CDNA in both sense and anti-sense orientation ( $E P_{2}$ sense and $\left.E_{2} A S\right)$. Orientation was confirmed by restriction fragment analysis, orientation-specific polymerase chain reaction, and cycle sequencing.

Transfection of HaCat cells in T75 flasks was done in log growth-phase nonconfluent cultures using $7 \mu \mathrm{g}$ of plasmid DNA and lipofectamine per the manufacturer's instructions (Life Technologies, Inc., Gaithersburg, MD). Stable transfectants were selected and maintained in the presence of geneticin (400 to $800 \mu \mathrm{g} / \mathrm{ml}$ ). Geneticin resistant clonal populations were selected using cloning chambers. We selected for further study six $\mathrm{EP}_{2}$ sense and five vector control clones that exhibited the highest agonist-induced cAMP production (see Figure $3 \mathrm{~A}$ ), as well as eight $E P_{2} A S$ clones that showed the greatest reduction in agonist-induced CAMP production (see Figure 3B).

For transient transfection of COS-7 cells, the $\mathrm{EP}_{2}$ receptor was first subcloned into the pcDNA3.0 expression vector (EP 2 -pcDNA3.0) (Invitrogen Corp., Carlsbad, CA). The $\mathrm{EP}_{2}$ sense-MIRB construct was digested with EcoRl and $X b a l$ to release the $\mathrm{EP}_{2}$ receptor open reading frame. After agarose gel electrophoresis, the $\mathrm{EP}_{2}$ receptor fragment was band purified. The purified EcoRI/Xbal fragment was then ligated into the EcoRI/Xbal sites of the pcDNA3.0 vector. Sense orientation of the $\mathrm{EP}_{2}$ receptor was verified by restriction enzyme digestion. Transient transfection was done in cells at $\sim 80 \%$ confluence using lipofectamine reagent. After 24 hours, membrane fractions were prepared as described below.

\section{In Vitro Translation}

In vitro translation was performed using a coupled transcription-translation reticulocyte lysate kit per the manufacturer's 
instructions ( $T_{N} T$-SP6 Coupled Reticulocyte Lysate System; Promega Corp., Madison, WI). An $\mathrm{EP}_{2}-$ pcDNA3.0 expression vector (see above), containing an SP6 promoter upstream of the $\mathrm{EP}_{2} \mathrm{cDNA}$ in sense orientation, was used. The reaction was performed in the presence of $40 \mu \mathrm{Ci}$ of $\left[{ }^{35} \mathrm{~S}\right]$ methionine (NEN Life Sciences, Boston, MA) and 1:50 volume of protease inhibitor cocktail (Sigma). A luciferasepositive control vector supplied by the manufacturer was used as a positive control.

\section{Total Cell Lysates/Membrane Preparations}

Crude membrane pellets were isolated as described. ${ }^{32}$ Total cell lysates were prepared by scraping washed cells into nonreducing $4 \%$ Laemmli's buffer. Protein was determined using the DC protein assay (Bio-Rad Laboratories, Hercules, CA).

\section{Immunoblots}

$\mathrm{EP}_{2}$ receptor immunoblots were performed using membrane preparations that were boiled for 5 minutes in an equal volume of $4 \%$ Laemmli's buffer containing bromphenol blue and $4 \% \beta$-mercaptoethanol. Samples were then electrophoresed in sodium dodecyl sulfate-polyacrylamide gel electrophoresis (SDS-PAGE) gels using prestained protein molecular weight markers. After transfer to nitrocellulose or polyvinylidene difluoride membranes, Ponceau S staining of membranes or Coomassie staining (GelCode Blue, Pierce Chemicals, Rockford, IL) of the gels was performed to verify equal loading. Blocking was done using Tris-buffered saline containing 0.05 to $0.1 \%$ Tween $20,5 \%$ nonfat dry milk, and $1 \%$ normal goat serum. Immunodetection was performed using mouse monoclonal anti-human $\mathrm{EP}_{2}$ receptor antibody (clone 2B4) at a concentration of $0.4 \mu \mathrm{g} / \mathrm{ml}$ for 1 hour at room temperature followed by sheep anti-mouse IgG$F\left(a b^{\prime}\right)_{2}$-peroxidase conjugate $(1: 2000)$ for 30 to $45 \mathrm{~min}$ utes. Primary and secondary antibodies were diluted in TBST containing $1 \%$ milk and $1 \%$ normal goat serum. Immunoreactive bands were detected by enhanced chemiluminescence (Renaissance ECL reagent; NEN Life Sciences, Boston, MA). Extremely careful and consistent washing and blocking was required with this antibody to avoid numerous nonspecific bands. For peptide competition, anti-EP $\mathrm{P}_{2}$ receptor antibody was incubated with or without 0.5 to $1 \mathrm{mg}$ of $\mathrm{EP}_{2}$-free peptide dissolved in $1 \mathrm{ml}$ of $100 \mathrm{mmol} / \mathrm{L}$ Tris, $\mathrm{pH} 8.0$, containing $0.15 \mathrm{~mol} / \mathrm{L}$ $\mathrm{NaCl}$. After incubation for 1 to 2 hours at $37^{\circ} \mathrm{C}$, the reaction products were diluted with TBST containing $1 \%$ milk and $1 \%$ normal goat serum as above. For paxillin immunostaining, $40 \mu \mathrm{g}$ of total cell lysate was resolved by sodium dodecyl sulfate-polyacrylamide gel electrophoresis as above. After incubation with mouse monoclonal anti-paxillin antibody (Transduction Laboratories, Lexington, $\mathrm{KY}$ ), immunoreactive bands were detected as above.

\section{Cyclic-AMP Assays}

Transfectants were plated at a density of 40,000 cells/ well into 48 -well plates. One to 2 days after reaching confluence, media was suctioned and replaced with growth media containing $10 \mu \mathrm{g} / \mathrm{ml}$ of indomethacin. After 2 to 3 hours at $37^{\circ} \mathrm{C}$, the monolayer was washed twice with PBS containing $10 \mu \mathrm{g} / \mathrm{ml}$ of indomethacin. After washing, growth media containing $10 \mu \mathrm{g} / \mathrm{ml}$ of indomethacin was added. The cells were then incubated overnight (20 to 22 hours) after which the monolayers were washed four times with serum-free Dulbecco's modified Eagle medium containing $25 \mathrm{mmol} / \mathrm{L}$ of HEPES and $10 \mu \mathrm{g} / \mathrm{ml}$ of indomethacin (reaction buffer). After washing, $0.25 \mathrm{ml}$ of reaction buffer (prewarmed to $37^{\circ} \mathrm{C}$ ) was added and the cells were incubated at $37^{\circ} \mathrm{C}$ for 15 minutes. The $\mathrm{EP}_{2}$ receptor agonist, $11 \mathrm{~d}-\mathrm{PGE}_{1}(2 \mu \mathrm{g} / \mathrm{ml})$, was then added in $0.25 \mathrm{ml}$ of reaction buffer containing $4 \mathrm{mmol} / \mathrm{L}$ of 3-isobutyl-1-methylxanthine. Plates were incubated for $15 \mathrm{~min}$ utes at $37^{\circ} \mathrm{C}$ after which the media was aspirated and ice-cold $0.1 \mathrm{~N}$ of hydrochloric acid $(\mathrm{HCl})$ was added. Levels of CAMP were quantitated in the acid supernatants with a commercial CAMP EIA kit (Assay Designs, Ann Arbor, MI). Protein content in the $0.1 \mathrm{~N} \mathrm{HCl}$ supernatants was quantitated using the BCA protein assay (Bio-Rad).

\section{Skin Equivalents}

Fibroblast-containing dermal equivalents were first prepared using primary adult human fibroblasts at passage 3 to 5 by a modification of a previously described method. ${ }^{43}$ Dermal equivalents were prepared using $5 \times 10^{5}$ primary human fibroblasts and purified rat tail type I collagen (Collaborative Research/Becton Dickinson, BD Biosciences, Bedford, MA). Each dermal equivalent was allowed to contract for 4 to 7 days in a $30-\mathrm{mm}$ tissueculture dish. Skin equivalents were then prepared. Clonal populations of $\mathrm{HaCat}$ cells overexpressing the $\mathrm{EP}_{2}$ receptor in sense or anti-sense orientation and vector control cells were trypsinized and 1 to $2 \times 10^{5}$ cells were seeded onto the dermal equivalents using a $5-\mathrm{mm}$ internal diameter sterile glass cloning chamber. After 2 to 3 hours the cloning chambers were removed, and the skin equivalents were submerged in $\mathrm{HaCat}$ growth media. After 7 to 10 days, the skin equivalents were lifted to the air-liquid interface on sterile wire grids. After 3 to 7 days, the lifted skin equivalents were fixed in $10 \%$ buffered formalin, paraffin-embedded, and stained with hematoxylin and eosin (H\&E) for light microscopic examination. For butaprost- and 11d-PGE 1 -treated clones (see Figures 7 and 8), cells were pretreated with agonist for 3 days before seeding onto dermal equivalents. Growth media containing butaprost, 11d-PGE 1 , or vehicle was changed every 2 days during both submerged culture and culture at the air-liquid interface.

H\&E-stained slides were prepared from three separate experiments. $\mathrm{EP}_{2} \mathrm{AS}$ clones were used at passage numbers ranging from 4 to 19 , whereas Mirb and $\mathrm{EP}_{2}$ sense clones were at passage number 4 to 22. Depth of invasion (in $\mu \mathrm{m}$ ) was assessed at the five deepest points of invasion for each clone using an Olympus BH-2 microscope equipped with a micrometer. Depth was measured perpendicular to the epidermal-dermal junction, starting from the epidermal-dermal junction to the deepest point of each invasive cell cluster that was measured. 


\section{Immunohistochemistry}

Formalin-fixed, paraffin-embedded skin equivalents were sectioned at $5 \mu \mathrm{m}$ thickness and attached to poly-Llysine-coated slides. Tissue sections were deparaffinized in xylene and rehydrated in 100\%, 95\%, and $70 \%$ ethanol for 5 minutes each, followed by a 6-minute incubation in water. Antigen retrieval was performed by boiling the slides for 10 minutes in $0.01 \mathrm{~mol} / \mathrm{L}$ of citrate buffer, $\mathrm{pH}$ 6.0. The container containing the slides in citrate buffer was then removed from the heat source and allowed to cool at room temperature for 20 minutes. Immunohistochemical staining was performed using a Zymed Histostain Plus AEC kit (Zymed Laboratories, South San Francisco, CA) following the manufacturer's instructions. Primary antibody (clone 2B4) or an isotype control (mouse IgG2a-к; DAKO Corp., Carpinteria, CA) was added at $5 \mu \mathrm{g} / \mathrm{ml}$ in PBS containing $0.1 \%$ BSA and $10 \%$ CAS block (Zymed Laboratories) and incubated for 1 hour at room temperature. Immunolabeling was detected using AEC substrate.

\section{Statistical Analysis}

Statistical analysis was done using a one-tailed unpaired or a two-tailed one sample $t$-test with Graphpad Prism software (GraphPad Prism 3.0 Software, San Diego, CA).

\section{Results}

\section{$E P_{2}$ and $E P_{3}$ Receptor Expression in HaCat} Cells

By Northern hybridization, HaCat cells express similar amounts of $\mathrm{EP}_{2}$ receptor mRNA compared with primary human keratinocytes (PHKs) (Figure 1A). However, both $\mathrm{EP}_{3}$ and $\mathrm{EP}_{4}$ receptors are also known to modulate CAMP production and we have previously demonstrated that PHKs express both $\mathrm{EP}_{3}$ and $\mathrm{EP}_{4}$ receptor mRNA. ${ }^{17}$ To ensure that prostaglandin receptor modulation of CAMP occurred primarily through the $\mathrm{EP}_{2}$ receptor in $\mathrm{HaCat}$ cells, $\mathrm{EP}_{3}$ and $\mathrm{EP}_{4}$ receptor expression was also studied. In $\mathrm{HaCat}$ cells, no $\mathrm{EP}_{4}$ receptor mRNA was observed by Northern blot, although $\mathrm{EP}_{4}$ receptor expression was detected by reverse transcriptase-polymerase chain reaction (data not shown). This appears to be similar to $\mathrm{EP}_{4}$ receptor expression in PHKs, where only trace amounts of $\mathrm{EP}_{4}$ receptor message are observed by Northern blot. ${ }^{17}$ In addition, $\mathrm{EP}_{3}$ receptor expression appears to be dramatically reduced in $\mathrm{HaCat}$ cells compared with PHKs. HaCat cells express at least trace amounts of the $\mathrm{EP}_{3}$ receptor transcript by reverse transcriptase-polymerase chain reaction (data not shown). To better quantitate the relative expression of the $\mathrm{EP}_{3}$ receptor in both $\mathrm{PHKs}$ and $\mathrm{HaCat}$ cells, we examined $\mathrm{EP}_{3}$ receptor expression using an RNase protection assay (Figure 1B). RNA from both U-937 cells and PHKs from two separate individuals exhibited a protected fragment of the correct size when incubated with the $\mathrm{EP}_{3}$ anti-sense riboprobe. No detect-
A.
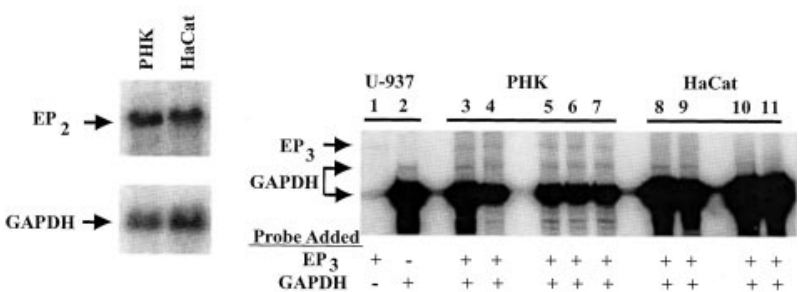

Figure 1. $\mathrm{EP}_{2}$ receptor mRNA expression in PHKs and HaCat cells: A: Northern hybridization showing approximately equivalent expression of $\mathrm{EP}_{2}$ receptor in both nonconfluent PHKs and HaCat cells. Hybridization was done with a ${ }^{32} \mathrm{P}$-labeled $\mathrm{EP}_{2}$ receptor riboprobe (top) or housekeeping GAPDH riboprobe (bottom). Each lane represents $7 \mu \mathrm{g}$ of poly(A)+-enriched RNA. B: RNase protection assay demonstrating decreased $\mathrm{EP}_{3}$ receptor transcript in HaCat cells compared with adult PHKs. Total RNA was prepared from positive control U-937 cells (lanes 1 and 2), adult PHKs from two separate individuals (individual I, lanes 3 and 4; individual II, lanes 5, 6 and 7), and HaCat cells (lanes 8 to $\mathbf{1 1}$ ). Lanes 3, 5, 8, and 10 represent total RNA isolated from nonconfluent cultures. Lanes 4, 7, 9, and 11 represent total RNA isolated from cultures at 3 to 4 days after confluence. Lane 6 represents RNA isolated from a culture that had just reached confluence. Cellular RNA (10 $\mu \mathrm{g}$ for lanes 1-7, $20 \mu \mathrm{g}$ for lanes 8 and $\mathbf{9}$, or $40 \mu \mathrm{g}$ for lanes 10 and 11) was incubated with a $\left[{ }^{32} \mathrm{P}-\mathrm{UTP}\right]-$ labeled $\mathrm{EP}_{3}$ and/or a GAPDH riboprobe followed by RNase A/T1 digestion. Protected fragments were visualized using a phosphorimager after nondenaturing polyacrylamide electrophoresis as described in Materials and Methods. Lane 1 represents the protected $\mathrm{EP}_{3}$ fragment observed in positive control RNA hybridized with only the $\mathrm{EP}_{3}$ riboprobe. Lane 2 represents the protected fragments when only the GAPDH riboprobe is hybridized to control RNA.

able $\mathrm{EP}_{3}$ receptor RNA was observed in HaCat cells, even at much higher RNA concentrations.

\section{$E P_{2}$ Receptor Expression Using an Anti-Human $E P_{2}$ Receptor Monoclonal Antibody}

To further examine the expression of the $\mathrm{EP}_{2}$ receptor in HaCat cells and PHKs, we generated a specific monoclonal antibody that recognizes an amino terminal epitope on the human $\mathrm{EP}_{2}$ receptor. The specificity of the monoclonal antibody for the $\mathrm{EP}_{2}$ amino terminal peptide, but not the multiple antigen peptide core sequence or an $\mathrm{EP}_{3}$ amino terminal peptide, is demonstrated in Figure 2A.

We next used a rabbit reticulocyte lysate in vitro translation system to demonstrate that the $\mathrm{EP}_{2}$ receptor, in the absence of posttranslational modifications, ${ }^{45}$ runs at a molecular weight of $\sim 30 \mathrm{kd}$ (Figure 2B). This 30-kd band was observed after in vitro translation in the presence and absence of protease inhibitors (data not shown). In Figure $2 \mathrm{C}$, HaCat cells are shown to express a similar 30-kd immunoreactive band as well as a 43- to 45-kd immunoreactive band. In contrast, PHKs express primarily a 52-kd protein band (Figure 2D).

To further demonstrate that the immunoreactive bands observed with the 2B4 monoclonal antibody represent the $\mathrm{EP}_{2}$ receptor despite their different molecular weights, a separate commercially available anti-hEP 2 receptor antibody was used (Cayman Chemical). This antibody was found to detect similar immunoreactive bands $(\sim 30,43$ to 45 , and $52 \mathrm{kd})$ in COS-7 membrane preparations transiently-transfected with an $\mathrm{EP}_{2}$-receptor expression vector (Figure 2E). 


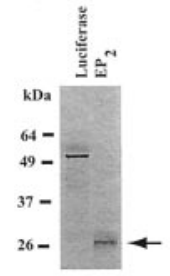

B.
A.
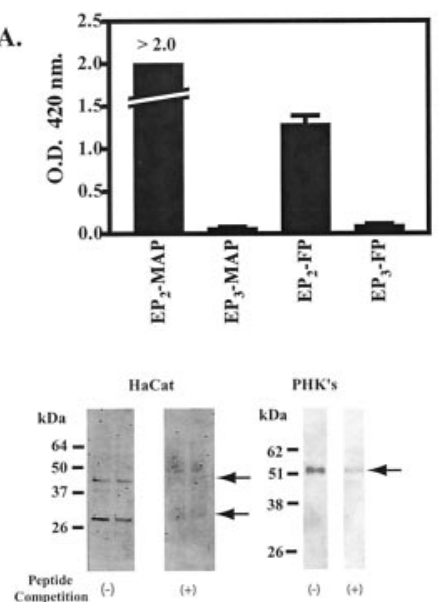

C.

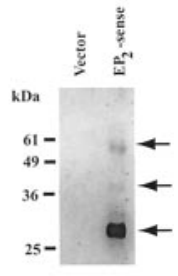

E.
Figure 2. Validation of the anti-human $\mathrm{EP}_{2}$ receptor monoclonal antibody. A: The monoclonal anti- $\mathrm{EP}_{2}$ antibody binds specifically to the immunogenic $\mathrm{EP}_{2}$ amino-terminal peptide sequence. An amino-terminal $\mathrm{EP}_{2}$ peptide coupled to a multiple antigen peptide core $\left(\mathrm{EP}_{2}-\mathrm{MAP}\right)$ was used to elicit the anti-EP ${ }_{2}$ receptor antibody (clone $2 \mathrm{~B} 4$ ). An EIA was used to assess the ability of the anti-EP antibody to specifically recognize both the $\mathrm{EP}_{2}-\mathrm{MAP}$ and the $\mathrm{EP}_{2}$-free peptide sequence $\left(\mathrm{EP}_{2}\right.$-FP). A MAP peptide coupled to an aminoterminal $\mathrm{EP}_{3}$ peptide $\left(\mathrm{EP}_{3}-\mathrm{MAP}\right)$ and the corresponding free peptide $\left(\mathrm{EP}_{3}-\right.$ FP) are used as negative controls. The results represent the mean and SD for a single EIA done in triplicate. $\mathbf{B}$ : Electrophoretic mobility of the $\mathrm{EP}_{2}$ receptor core protein lacking posttranslational modifications. $\left.{ }^{35} \mathrm{~S}\right]$-Methionine was incorporated into both the $\mathrm{EP}_{2}$ receptor and luciferase by in vitro translation using a rabbit reticulocyte lysate method. Radiolabeled $\mathrm{EP}_{2}$ receptor and luciferase were electrophoresed on a $10 \%$ sodium dodecyl sulfate-polyacrylamide gel electrophoresis gel. Bands were detected by autoradiography. C and D: Immunoblot of membrane preparations from HaCat cells $(\mathbf{C})$ and PHKs (D) with the monoclonal anti-hEP ${ }_{2}$ receptor antibody (clone $2 \mathrm{~B} 4$ ). Immunoblots were done in the presence $(+)$ and absence $(-)$ of competing free peptide. $\mathbf{E}: \mathrm{EP}_{2}$ receptor expression in membrane preparations from COS-7 cells transiently transfected with an $\mathrm{EP}_{2}$ expression vector. The immunoblot was done using a commercial rabbit polyclonal anti-EP 2 receptor antibody (Cayman Chemical, Ann Arbor, MI). The vector control consisted of COS-7 cells transiently transfected with the empty pcDNA3.0 vector.

\section{Validation of Gain/Loss of EP $P_{2}$ Receptor Expression in $E P_{2}$ Sense- and $E P_{2}$ Anti-Sense-Expressing Clones}

We next generated clonal populations of HaCat cells stably expressing the $\mathrm{EP}_{2}$ receptor in both the sense (S1-S6), and anti-sense orientation (AS1-6, 8, and 9), as well as clones containing empty vector (M1-M5). G418resistant clones were selected for either gain or loss of functional $\mathrm{EP}_{2}$ receptor by agonist (11d-PGE $\mathrm{E}_{1}$ )-induced CAMP production (Figure 3, A and B). To ensure that the loss or gain of agonist-induced CAMP was because of alteration of $\mathrm{EP}_{2}$ receptor expression, $\mathrm{CAMP}$ studies were also done using a second agonist (butaprost) with similar results (data not shown).

Clones were further characterized for loss or gain of

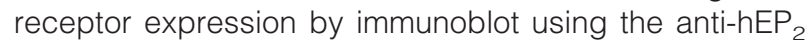
receptor antibody (clone 2B4). In Figure 3C, increased immunoreactivity of both the 30-kd and 43- to 45-kd bands were noted in the six $\mathrm{EP}_{2}$ sense clones. The greatest increase was observed in the 30-kd band. In Figure $3 \mathrm{D}$, six of the $\mathrm{EP}_{2} \mathrm{AS}$ clones are shown that demonstrate a decreased to absent 43- to 45-kd band compared with vector control cells. The 30-kd band did not seem to be appreciably affected in the $\mathrm{EP}_{2} \mathrm{AS}$ transfectants.

\section{Morphology, Growth Rates, and Plating Efficiencies of Clonal Transfectants}

$\mathrm{EP}_{2} \mathrm{AS}$-transfected clones demonstrated marked heterogeneity in cell size and shape compared with $\mathrm{EP}_{2}$ sense and control clones, particularly at low confluence (Figure 4; $A$ to $C$ ). Because $E_{2}$ receptor activation stimulates growth in $\mathrm{PHKs}$, we examined growth rates in $\mathrm{EP}_{2} \mathrm{AS}$ and $\mathrm{EP}_{2}$ sense clones. Nonconfluent growth rates were compared from day 1 after plating until day 4 after plating. There was a modest decrease in growth rates for $\mathrm{EP}_{2} \mathrm{AS}$ clones compared with vector controls (see Figure 4D). $\mathrm{EP}_{2}$ sense clones demonstrated a trend toward increased growth rates. Neither $E_{2}$ sense nor $E_{2} A S$ growth rates achieved statistical significance. Similar results were observed using 5-bromo-2'-deoxyuridine incorporation (data not shown).

We also examined plating efficiencies of the $\mathrm{EP}_{2}$ sense and $\mathrm{EP}_{2} \mathrm{AS}$ clones compared with vector control clones (Figure 4E). Changes in plating efficiencies were quantitated by counting both attached and nonattached cells after an overnight incubation. Compared with vector control clones, $\mathrm{EP}_{2}$ sense clones demonstrated an increased number of attached cells and a corresponding decreased number of nonattached cells. In contrast, $E_{2} A S$ clones exhibited decreased plating efficiencies compared with vector control clones.

\section{$E P_{2}$ Anti-Sense Clones Demonstrate Increased} Invasiveness

HaCat cells are a human keratinocyte cell line that are spontaneously immortalized but noninvasive after xenografting to nude mice. ${ }^{46}$ Because gain or loss of $\mathrm{EP}_{2}$ receptor expression was associated with alterations in plating efficiencies, we next examined whether $\mathrm{EP}_{2}$ receptor expression was associated with an invasive phenotype. To assess the invasive behavior of the transfected HaCat clones, we used a three-dimensional organ culture model of normal skin. Hematoxylin and eosin (H\&E)-stained sections of representative clones grown as skin equivalents are shown (Figure 5 ). $\mathrm{EP}_{2} \mathrm{AS}$ clones all demonstrated extensive deep invasion with marked branching and networking into the dermal compartment. Two representative $\mathrm{EP}_{2} \mathrm{AS}$ clones are shown in Figure 5, $A$ and $B$. Invasive foci were also seen in Mirb and $E P_{2}$ sense clones. However, these foci differed from those seen in $E_{2} A S$ clones in that only shallow fingers of invasion, or isolated islands of cells just below the epidermal/dermal junction, were evident (Figure 5; C to F).

Quantitatively, $\mathrm{EP}_{2} \mathrm{AS}$ clones exhibited more than a twofold increase in depth of invasion compared with vector controls and $\mathrm{EP}_{2}$ sense clones (Figure 6; $P<0.001$ ). In contrast, there was no significant difference between the depth of invasion in the $\mathrm{EP}_{2}$ sense clones compared with the vector control cells $(P=0.187)$. 

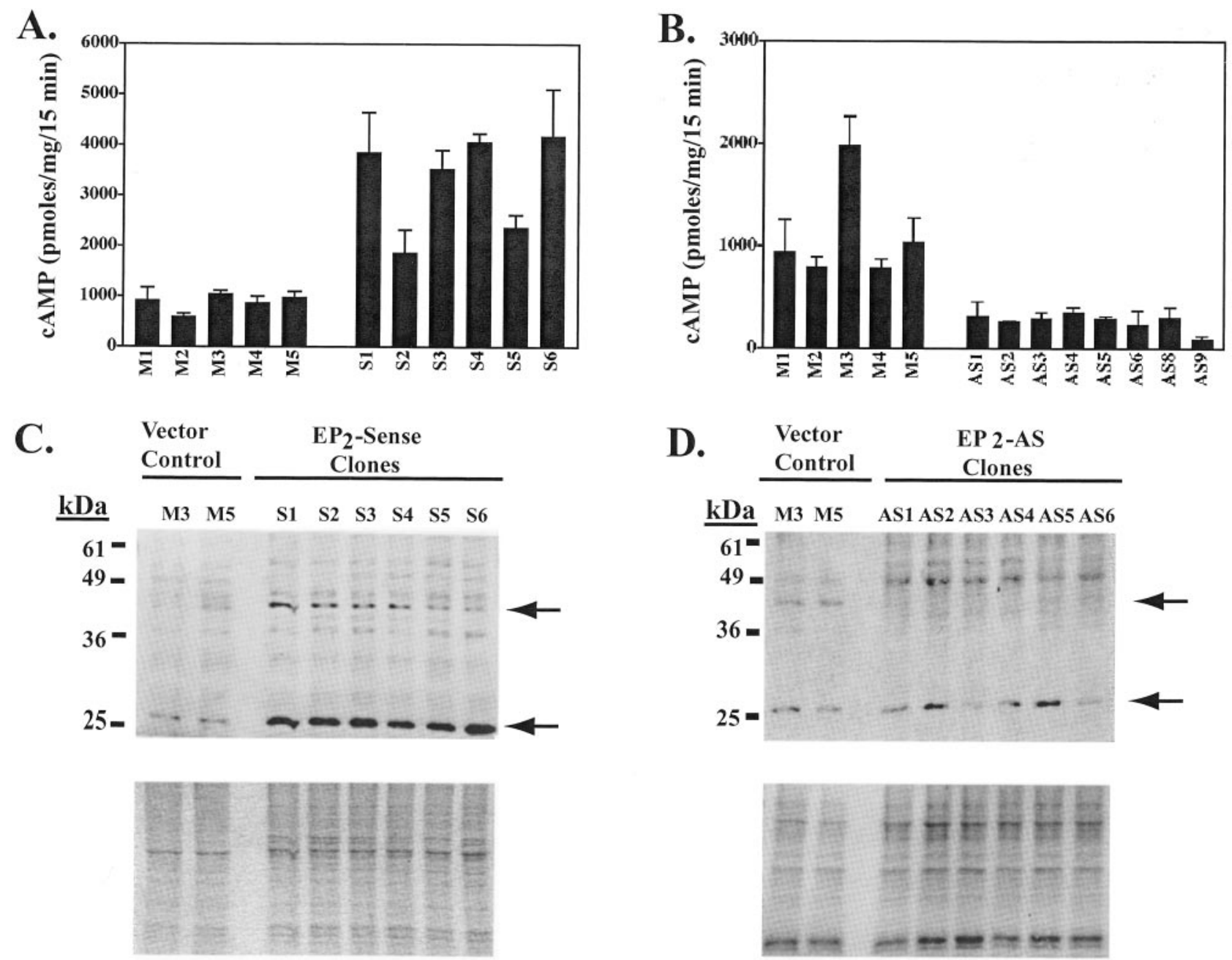

Figure 3. Alteration of $\mathrm{EP}_{2}$ receptor expression and function in clonal populations of $\mathrm{HaCat}$ cells stably transfected with $\mathrm{EP}_{2}$ sense and $\mathrm{EP}_{2} \mathrm{AS}$ expression constructs. A and B: Agonist-induced cAMP was measured in stably transfected clonal populations of HaCat cells expressing the EP 2 receptor in sense (A) or anti-sense (B) orientation. $\mathrm{EP}_{2}$ sense clones ( $\mathrm{S} 1$ to $\mathrm{S} 6$ ), $\mathrm{EP}_{2} \mathrm{AS}$ clones (AS1-6, 8, and 9), and empty vector pMIRB control clones (M1 to $\mathrm{M} 5$ ) were pretreated with indomethacin $(10 \mu \mathrm{g} / \mathrm{ml})$ overnight to block endogenous $\mathrm{PGE}_{2}$ formation. cAMP was then measured after a $15-$ minute stimulation with the EP $_{2}$ agonist $11 \mathrm{~d}-\mathrm{PGE}_{1}$ ( $1 \mu \mathrm{g} / \mathrm{ml}$ ). Isobutyl methylxanthine $(2 \mathrm{mmol} / \mathrm{L}$ ) was included to block cAMP phosphodiesterase activity. $\mathbf{C}$ and $\mathbf{D}$ : EP 2 receptor expression was evaluated by Western blot in both $\mathrm{EP}_{2}$ sense clones (18 $\mu \mathrm{g} /$ lane) (C, top) and $\mathrm{EP}_{2} \mathrm{AS}$ clones (12 $\left.\mu \mathrm{g} / \mathrm{lane}\right)$ (D, top) compared with two vector control clones (M3 and M5). Immunoblotting was performed using the monoclonal anti-hEP 2 receptor antibody (clone $2 \mathrm{~B} 4$ ). C, bottom: Coomassie-stained gel (after transfer). D, bottom Ponceau $\mathrm{S}$ stain of the membrane after transfer.

\section{Pharmacological Down-Regulation of $E P_{2}$ Receptors Induces an Invasive Phenotype in Vector Control Clones But Not $E_{2}$-Sense Clones}

The above observations prompted us to determine whether pharmacological down-regulation of $\mathrm{EP}_{2}$ receptors could reproduce the increased invasiveness seen in anti-sense clones. We used two chemically distinct $\mathrm{EP}_{2}$ receptor agonists to verify that any observed effect was because of alterations of $\mathrm{EP}_{2}$ receptor signaling. Treatment with the $\mathrm{EP}_{2}$ receptor agonist $11-\mathrm{dPGE}_{1}$ induced a marked increase in invasion depth in three vector control clones at concentrations of $1 \mathrm{ng} / \mathrm{ml}$ or more (Figure $7 \mathrm{~A}$ ). A similar increase in invasion was observed in two vector control clones treated with $1 \mu \mathrm{g} / \mathrm{ml}$ of the less potent, but more selective, $\mathrm{EP}_{2}$ receptor agonist butaprost (Figure
7B). There was no significant change in invasion depth in $\mathrm{EP}_{2}$ sense clones treated with either receptor agonist (data not shown).

We next examined $\mathrm{EP}_{2}$ receptor expression by immunohistochemistry in formalin-fixed, paraffin-embedded sections of skin equivalents made with $\mathrm{EP}_{2}$ sense and vector control clones treated with the more selective agonist butaprost. In Figure 8, representative photomicrographs are shown of $\mathrm{EP}_{2}$ receptor immunostaining in skin equivalents prepared with $\mathrm{EP}_{2}$ sense and vector control clones. To assess the affects of $\mathrm{EP}_{2}$ receptor agonist on receptor expression and epidermal invasiveness, the skin equivalents were treated with vehicle, or $0.1 \mu \mathrm{g} / \mathrm{ml}$ or $1.0 \mu \mathrm{g} / \mathrm{ml}$ butaprost. In the vehicle controls, increased $\mathrm{EP}_{2}$ receptor immunoreactivity is noted in the epidermis constructed from the $\mathrm{EP}_{2}$ sense clone (Figure 8A) compared with the vector control (Figure $8 D$ ). In skin equiv- 
A.

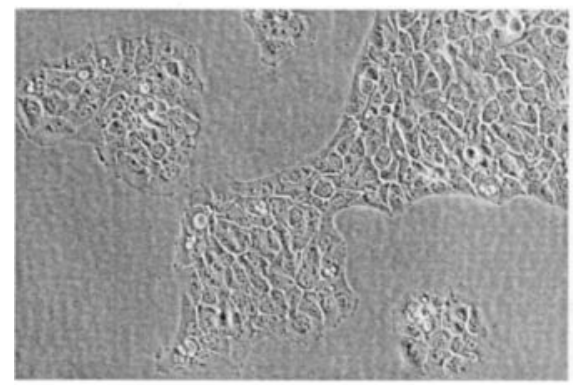

B.

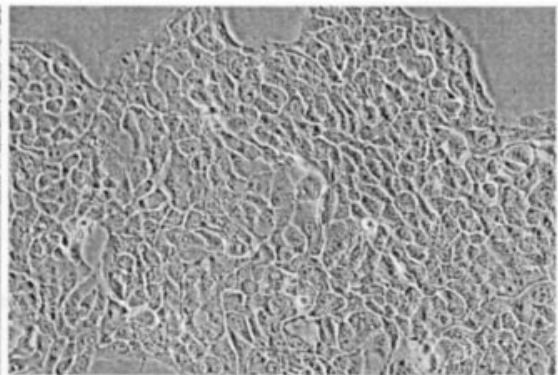

C.

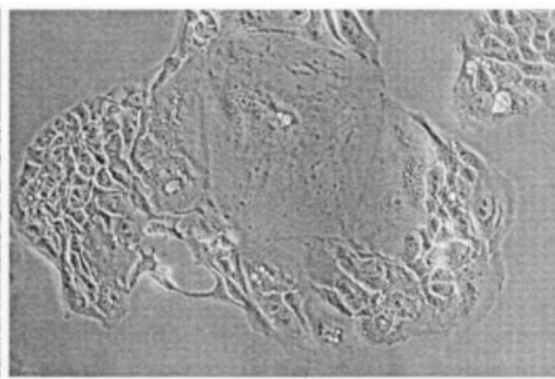

\section{Growth Assay}

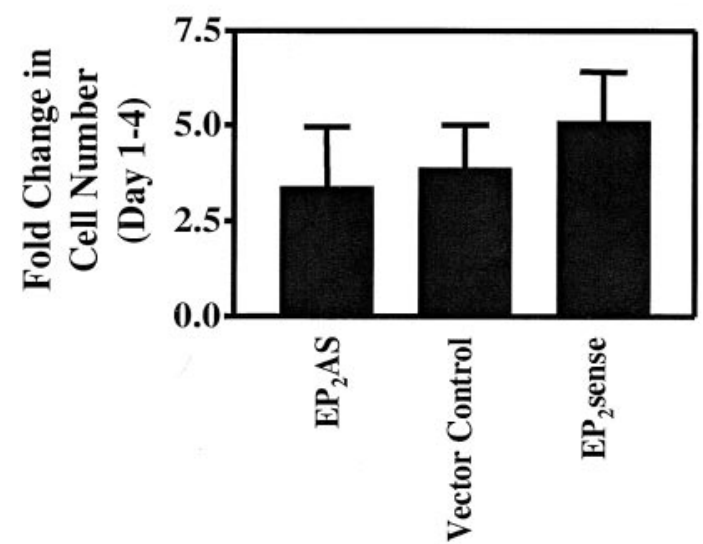

E. Plating Efficiency

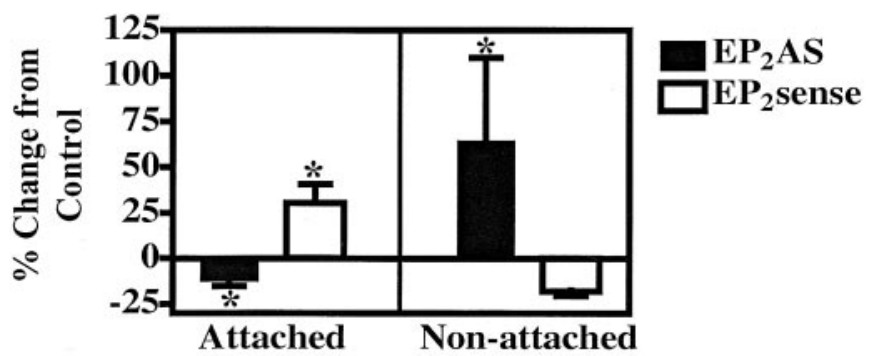

Figure 4. Tissue culture morphology, growth rates, and plating efficiency of $\mathrm{EP}_{2}$ sense/AS clones. Photomicrographs of representative empty vector Mirb clone (M5) (A), $\mathrm{EP}_{2}$ sense clone (S2) (B), and $\mathrm{EP}_{2} \mathrm{AS}$ clone (AS8) (C) grown on tissue culture plastic. D: Growth rates were determined for clonal populations of HaCat cells overexpressing sense or anti-sense (AS) $\mathrm{EP}_{2}$ receptor constructs compared with empty vector controls. Cells were counted at day 1 and at day 4 after plating. Results are expressed as the mean and SD for the fold change in cell number from day 1 through 4 . The data represents a single representative experiment done in triplicate (values $=3.41 \pm 1.53,3.89 \pm 1.12$, and $5.12 \pm 1.28$ for $\mathrm{EP}_{2} \mathrm{AS}$, vector controls, and $\mathrm{EP}_{2}$ sense clones, respectively). $\mathbf{E}$ : Plating efficiency was determined by counting both attached and nonattached cells after an overnight incubation on tissue culture plates. For cellular attachment, the results represent the mean and SE for four separate experiments for $\mathrm{EP}_{2} \mathrm{AS}$ clones and six separate experiments for $\mathrm{EP}_{2}$ sense clones done in duplicate or triplicate wells $(*, P<$ $0.05)$. The data for nonattached cells represents mean and SD for a single experiment done in triplicate for $\mathrm{EP}_{2} \mathrm{AS}$ clones $(P<0.05)$ and the mean and $\mathrm{SE}$ for two separate experiments for $\mathrm{EP}_{2}$ sense clones $(P=0.053)$. Original magnifications, $\times 200(\mathbf{A}-\mathbf{C})$.

alents treated with 0.1 and $1 \mu \mathrm{g} / \mathrm{ml}$ butaprost, a decrease in $\mathrm{EP}_{2}$ receptor immunostaining was noted in both $\mathrm{EP}_{2}$ sense (Figure 8, B and $\mathrm{C}$ ) and vector controls (Figure 8, $E$ and $F)$. As expected, even at the highest concentration of butaprost, $\mathrm{EP}_{2}$ receptor immunostaining in the $\mathrm{EP}_{2}$ sense clone did not appear to be decreased beyond that observed for the vehicle-treated vector control clone (Figure 7, C and D). Moreover, a concentration-dependent increase in invasiveness is observed in the agonisttreated vector control skin equivalent, but not in skin equivalents made with $\mathrm{EP}_{2}$ sense cells (Figure 7B and Figure 8, E and F). In contrast, $\mathrm{EP}_{2}$ sense clones showed only an increase in epidermal thickness, suggesting that agonist treatment induced only epidermal hyperplasia.

\section{Loss of EP 2 Receptor Expression Is Associated with Decreased Paxillin Expression}

Because manipulation of $\mathrm{EP}_{2}$ receptor expression had effects on both plating efficiency and invasiveness, we questioned whether $\mathrm{EP}_{2}$ receptor expression alters expression of cellular proteins known to govern cellular attachment. Because paxillin expression is known to be decreased in squamous cell carcinomas, ${ }^{38}$ we examined whether changes in paxillin expression occurred in the $E P_{2} A S$ clones. Paxillin expression is shown to be decreased in four separate $\mathrm{EP}_{2} \mathrm{AS}$ clones compared with vector control clones (Figure 9A). A similar decrease in paxillin expression was observed in all of the $E_{2} A S$ clones. There was no change in paxillin expression in $\mathrm{EP}_{2}$ sense clones (data not shown).

Based on the above observations, it would be expected that agonist-induced down-regulation of $\mathrm{EP}_{2}$ receptors would result in a further decrease in paxillin expression. In Figure 9B, prolonged $\mathrm{EP}_{2}$ agonist exposure $\left(1 \mathrm{ng} / \mathrm{ml}\right.$ of $\left.11 \mathrm{~d}-\mathrm{PGE}_{1}\right)$ resulted in reduced expression of the 43- to $45-k d E_{2}$ receptor band in two $E P_{2} A S$ clones (Figure 9B, bottom). This decrease in $\mathrm{EP}_{2}$ receptor expression was associated with a further reduction in paxillin expression (Figure 9B, top). 

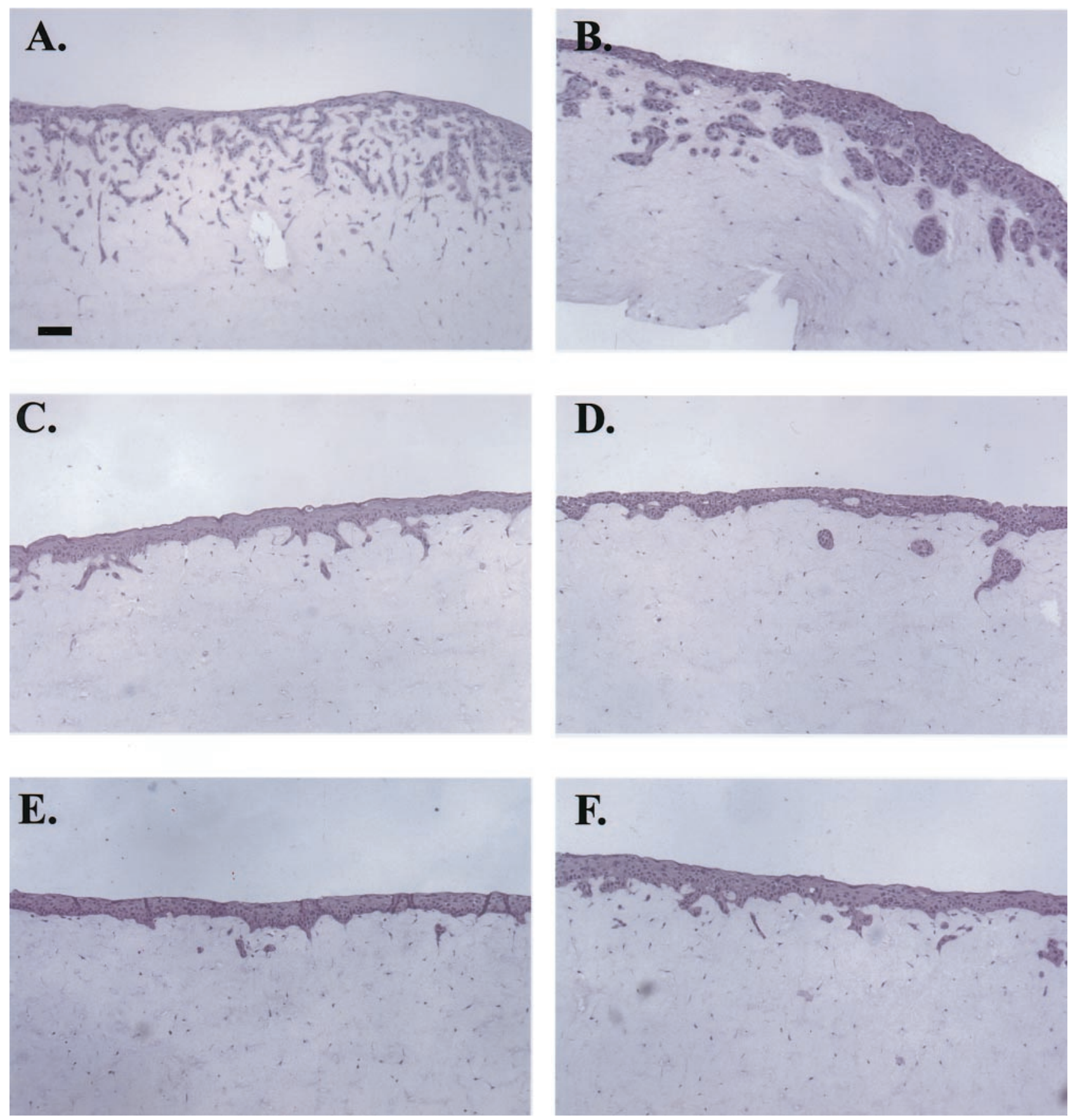

Figure 5. $\mathrm{EP}_{2} \mathrm{AS}$ clones exhibit increased invasiveness in skin equivalents. Photomicrographs of H\&E-stained slides of two $\mathrm{EP}_{2} \mathrm{AS}$ clones $(\mathbf{A}$ and $\mathbf{B})$, two vector control clones $(\mathbf{C}$ and $\mathbf{D})$, and two $\mathrm{EP}_{2}$ sense clones $(\mathbf{E}$ and $\mathbf{F})$. Scale bar, $100 \mu \mathrm{m}(\mathbf{A})$. Original magnifications, $\times 100$.

\section{Discussion}

Previous reports have suggested that loss of prostaglandin $\mathrm{E}$ receptor radioligand-binding activity is associated with more advanced malignancy. ${ }^{33,35-37}$ Moreover, treatment of metastatic murine mammary tumor cells with $\mathrm{PGE}_{2}$ receptor antagonists leads to decreased $\mathrm{PGE}_{2^{-}}$ induced CAMP production and increased lung metastasis. ${ }^{47}$ We demonstrate that loss of $\mathrm{EP}_{2}$ receptors in an immortalized, but nontumorigenic human keratinocyte cell line (HaCat) results in increased invasiveness in an organ culture model. Loss of $\mathrm{EP}_{2}$ receptor expression by either molecular intervention or by pharmacological down-regulation both resulted in a marked increase in invasiveness. Because prostaglandin receptors are known to undergo ligand-dependent receptor down-regulation, this strongly suggests that increased COX-2 and $\mathrm{PGE}_{2}$ production in advanced malignancy may lead to a more aggressive tumor as a result of ligand-dependent receptor down-regulation. Studies have been initiated to address this hypothesis by examining $\mathrm{EP}_{2}$ receptor expression in a large series of human tissue samples representing the spectrum of human cutaneous neoplasia, 


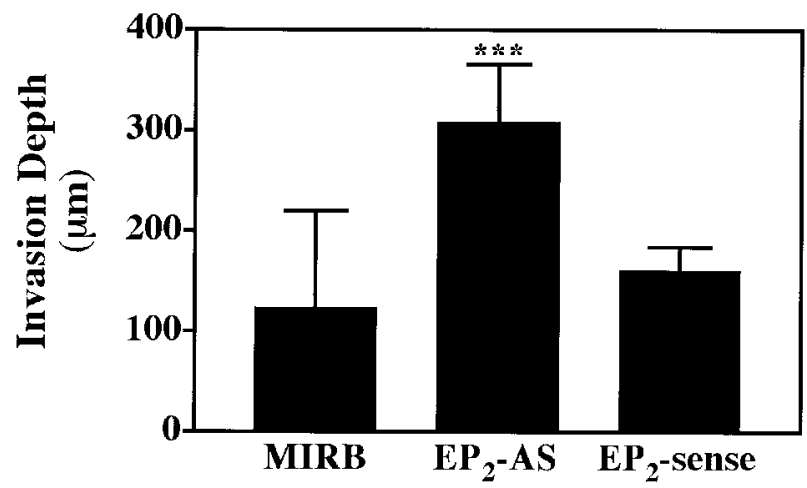

Figure 6. $\mathrm{EP}_{2} \mathrm{AS}$ clones showed significantly greater depth of invasion compared with empty vector (Mirb) or $\mathrm{EP}_{2}$ sense clones. Depth of invasion (in $\mu \mathrm{m}$ ) was quantitated in H\&E-stained sections of formalin-fixed, paraffinembedded skin equivalents by measuring the five deepest points of invasion for each clone. Values represent the mean and SD from two to four separate skin equivalents for each clone. Values equal $123.3 \pm 96.9 \mu \mathrm{m}, 308.0 \pm 58.1$ $\mu \mathrm{m}$, and $161.1 \pm 22.7 \mu \mathrm{m}$ for Mirb, $\mathrm{EP}_{2} \mathrm{AS}$, and $\mathrm{EP}_{2}$ sense clones, respectively (*wak, $P<0.001$ compared with vector controls or $\mathrm{EP}_{2}$ sense clones)

from hyperplastic changes and early premalignant lesions to invasive carcinoma.

Although other EP receptors are expressed in HaCat cells, these data strongly support the $\mathrm{EP}_{2}$ receptor as key in this process. The $\mathrm{EP}_{3}$ and $\mathrm{EP}_{4}$ receptors, which are known to influence cAMP levels in other cell types, are present only in small amounts in HaCat cells. Moreover, changes in cellular invasiveness were also seen with pharmacological down-regulation of the $\mathrm{EP}_{2}$ receptors with two separate $\mathrm{EP}_{2}$-specific agonists. Finally, the $\mathrm{EP}_{2}$ receptor exhibits only modest DNA sequence homology with other EP receptor subtypes (21 to $27 \%$, Clustal Method, MegAlign Software; DNASTAR, Inc., Madison, $\mathrm{WI})$. Thus, it is unlikely that the use of the $\mathrm{EP}_{2}$ receptor cDNA in anti-sense orientation altered expression of other receptor subtypes.

By Western blot (Figure 2; C to E), we observed three separate immunoreactive bands for the $\mathrm{EP}_{2}$ receptor with apparent molecular weights of $\sim 30 \mathrm{kd}, 43$ to $45 \mathrm{kd}$, and $52 \mathrm{kd}$. Interestingly, HaCat cells expressed primarily the two lower molecular weight bands, whereas PHKs exhibited primarily the higher molecular weight band. This suggests that HaCat cells have a defect in posttransla-

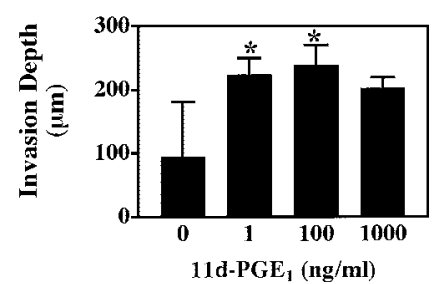

B.

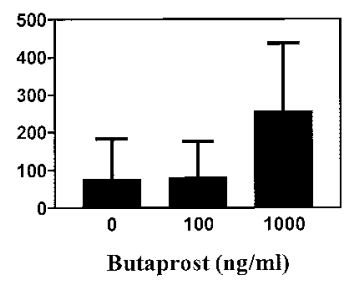

Figure 7. $\mathrm{EP}_{2}$ agonist exposure results in a marked increase in invasiveness in vector control clones. A: Three vector control clones were treated with vehicle, and $1 \mathrm{ng} / \mathrm{ml}, 100 \mathrm{ng} / \mathrm{ml}$, and $1000 \mathrm{ng} / \mathrm{ml}$ of $11 \mathrm{~d}-\mathrm{PGE}_{1}$ for 3 days before plating on dermal equivalents, and every other day thereafter. Skin equivalents were grown for 8 days submerged in growth media and for 3 days at the air-liquid interface. Results represent the mean and SE for depth of invasion into the dermal compartment $(*, P<0.05)$. B: Similar results for two vector control clones treated with vehicle, and $100 \mathrm{ng} / \mathrm{ml}$ and 1000 $\mathrm{ng} / \mathrm{ml}$ butaprost. tional modification of the $\mathrm{EP}_{2}$ receptor, although this receptor is functionally active based on agonist-dependent cAMP production. The 30-kd band present in HaCat cells exhibits a similar electrophoretic mobility to the core protein sequence observed after in vitro translation (Figure 2, $\mathrm{B}$ and $\mathrm{C})$. Interestingly, in COS-1 cells transfected with a hemagglutinin epitope-tagged $\mathrm{EP}_{2}$ receptor, immunoprecipitation with an anti-HA antibody demonstrated a similar lower band of $\sim 30 \mathrm{kd}$, as well as several higher molecular weight bands. ${ }^{48}$ Because $\mathrm{EP}_{2}$ receptors exhibit two putative $\mathrm{N}$-linked glycosylation sites, ${ }^{44}$ this suggests that the 43- to 45-kd and 52-kd bands may represent partial and fully glycosylated receptor. A defect in receptor glycosylation is supported by a reported defect in $\mathrm{N}$-linked glycosylation in HaCat cells as well as other transformed keratinocyte cell lines. ${ }^{49}$ However, $\mathrm{PGE}_{2}$ coupled receptors may exhibit other posttranslational modifications including isoprenylation and phosphorylation. ${ }^{48,50}$

We have previously demonstrated that $\mathrm{EP}_{2}$ receptor activation stimulates growth in $\mathrm{PHKs} .{ }^{17}$ Thus, $\mathrm{EP}_{2}$ receptors might act as a tumor promoter early in cutaneous tumorigenesis. A tumor-promoting role for the $\mathrm{EP}_{2}$ receptor in other tissues is supported by the decreased growth of intestinal polyps observed in COX-2, EP 2 , and $E_{4}$ knockout mice crossed with MIN mice. ${ }^{18-21}$ This data would initially appear to conflict with our observations. Down-regulation of $\mathrm{EP}_{2}$ receptors might be expected to result in growth inhibition rather than increased invasiveness. In HaCat cells, gain or loss of $\mathrm{EP}_{2}$ receptor expression had only modest effects on cell growth. The lack of a marked effect on cell growth may be explained by the fact that HaCat cells have dual inactivating mutations of p53 and absent to decreased expression of cyclin-dependent kinase inhibitors. ${ }^{51,52}$ Thus, HaCat cells exhibit a blunted response to a number of stimuli that are growth inhibitory in primary keratinocytes. ${ }^{51}$ An analogous situation is observed with transforming growth factor- $\beta$. Transforming growth factor- $\beta 1$ inhibits growth of various normal tissues, but acts as a potent inducer of metastasis and invasion in neoplastic cells when cells acquire disruptions of normal cell cycle checkpoint controls. ${ }^{53}$

Although HaCat cells are aneuploid, exhibit a transformed phenotype, and appear to have acquired loss of several important tumor suppressor genes, they differ from many SCC cell lines in that HaCat cells express little COX-2 and produce much lower concentrations of $\mathrm{PGE}_{2}{ }^{54}$ This may contribute to their normally noninvasive phenotype. Based on this observation, it would be predicted that stably overexpressing COX-2 in HaCat cells would result in acquisition of an invasive phenotype.

One particular problem with our observations is that NSAID treatment might be expected to block ligand production, leading to loss of receptor signaling. Loss of receptor signaling might be expected to result in increased invasiveness. This clearly conflicts with various studies demonstrating that NSAIDs inhibit experimental invasion and metastasis both in vivo and in vitro. ${ }^{26-29}$ There are several possible explanations for this apparent discrepancy. In the face of a marked increase in COX-2 expression in late stage tumorigenesis, the ability of 

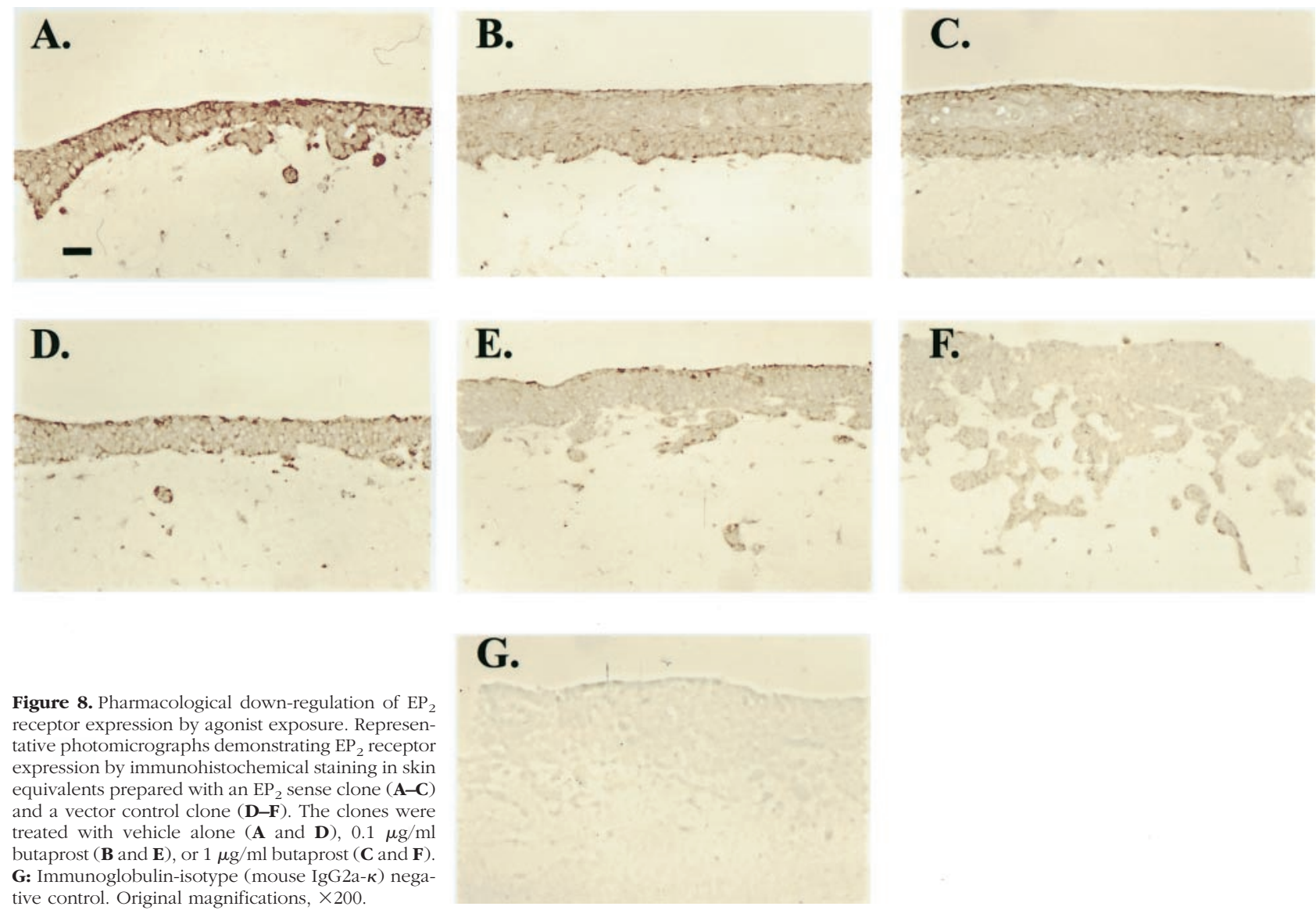

Figure 8. Pharmacological down-regulation of $\mathrm{EP}_{2}$ receptor expression by agonist exposure. Representative photomicrographs demonstrating $\mathrm{EP}_{2}$ receptor expression by immunohistochemical staining in skin equivalents prepared with an $\mathrm{EP}_{2}$ sense clone $(\mathbf{A}-\mathbf{C})$ and a vector control clone (D-F). The clones were treated with vehicle alone (A and D), $0.1 \mu \mathrm{g} / \mathrm{ml}$ butaprost (B and $\mathbf{E}$ ), or $1 \mu \mathrm{g} / \mathrm{ml}$ butaprost $(\mathbf{C}$ and $\mathbf{F}$ ). G: Immunoglobulin-isotype (mouse IgG2a- $\kappa$ ) negative control. Original magnifications, $\times 200$.

NSAIDs to completely block $\mathrm{PGE}_{2}$ production may be limited. This is supported by a recent study showing that NSAID treatment of HT29 colon cancer cells containing high levels of COX-2 expression reduced $\mathrm{PGE}_{2}$ concentrations to levels equal to or slightly higher than untreated colon cancer cell lines with low levels of COX-2 expression. ${ }^{55}$ Moreover, NSAIDs are known to induce expression of $\mathrm{PGE}_{2}$ receptors. ${ }^{56,57}$ Thus, increased receptor expression may be able to compensate for reduced $\mathrm{PGE}_{2}$ production. Finally, NSAIDs have been shown to block production of a secondary $\mathrm{PGE}_{2}$ metabolite, prostaglandylinositol cyclic phosphate (cyclic PIP), which is a direct inhibitor of adenylate cyclase. ${ }^{58}$ Thus, loss of $\mathrm{PGE}_{2}$-mediated CAMP synthesis in NSAID-treated cells may be partially compensated by loss of this inhibitory pathway.

Our data seems to conflict with data reported by several groups that demonstrate increased COX-2 expression and $\mathrm{PGE}_{2}$ production associated with increased mRNA expression for both the $\mathrm{EP}_{2}$ and $\mathrm{EP}_{4}$ receptors in human cervical and endometrial cancer tissues. 2,59,60 This might suggest that the effects that we observe are cell- or tissue-type-specific. Alternatively, the increased transcription of the $\mathrm{EP}_{2}$ and $\mathrm{EP}_{4}$ receptors may simply represent a compensatory increase in receptor transcription as a result of receptor down-regulation. Increased $\mathrm{PGE}_{2}$ receptor transcription has been demonstrated in cells treated with COX inhibitors. ${ }^{56,57}$ This suggests that receptor expression is mediated via a negative feedback loop, which has been documented for both the $\mathrm{EP}_{4}$ and the $\mathrm{FP}_{\mathrm{A}}$ isoform of $\mathrm{PGF}_{2 \alpha}$ receptor. ${ }^{61,62}$ If this model also applies to $\mathrm{EP}_{2}$ receptors, receptor down-regulation would be expected to release the negative feedback loop resulting in increased receptor transcription.

In the above studies, increased receptor mRNA was also associated with an increase in $\mathrm{PGE}_{2}$-stimulated cAMP production. ${ }^{59,60}$ However, the increased $\mathrm{PGE}_{2^{-}}$ stimulated CAMP as reported by both groups was normalized to total tissue protein. The increased tumor-derived CAMP may simply represent the increased cellularity of neoplastic tissue compared with normal epithelium. This idea is supported by a parallel increase in forskolin-induced CAMP in the tumor tissues in one of the reports. ${ }^{59}$

A potential mechanism for both the changes in cellular adhesion and an invasive phenotype is suggested by the loss in expression of the focal adhesion protein paxillin (see Figure 9). Although cAMP-mediated signaling is known to modulate the phosphorylation status of paxillin, ${ }^{39,63}$ a role for $\mathrm{PGE}_{2}$ or $\mathrm{CAMP}$ signaling in regulating paxillin expression has not been previously shown. Paxillin serves as a scaffolding protein, which is required for integrin-mediated focal adhesion assembly. Assembly and disassembly of focal adhesions is necessary for cellular movement and mediates cell contact with extracellular matrix. ${ }^{41}$ In small cell lung cancer cell lines, loss of paxillin expression results in increased cellular motility. ${ }^{40}$ The functional activity of paxillin is known to be mediated by phosphorylation by serine, 
A.

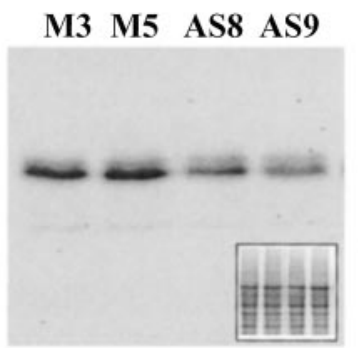

M3 M5 AS3 AS4

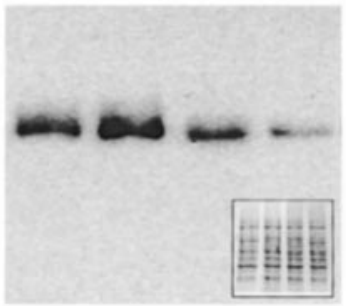

B.

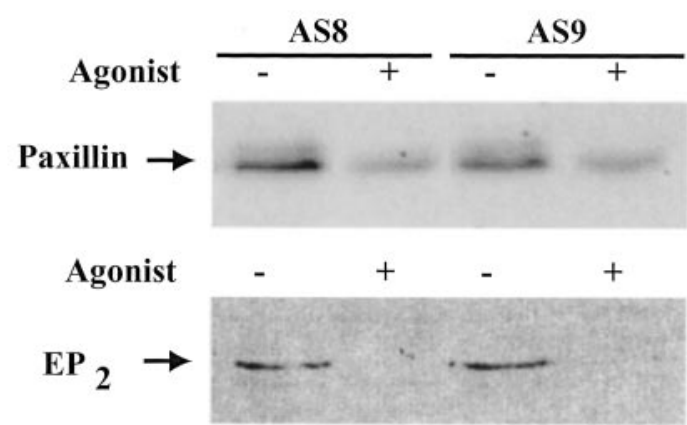

Figure 9. A: Paxillin is down-regulated in $\mathrm{EP}_{2} \mathrm{AS}$ clones. Total cell lysates (20 $\mu \mathrm{g} /$ lane) from two vector controls (M3, M5) and four $\mathrm{EP}_{2} \mathrm{AS}$ clones (AS8 and AS9, left; AS3 and AS4, right) were separated on a $12 \%$ sodium dodecyl sulfate-polyacrylamide gel electrophoresis gel. After transfer to nitrocellulose membranes, paxillin immunostaining was performed. The paxillin band is seen at $\sim 65 \mathrm{kd}$. The inset represents Ponceau S staining of the nitrocellulose membrane. B: Pharmacological down-regulation of the $\mathrm{EP}_{2}$ receptor is associated with a further loss in paxillin expression. Top: An immunoblot for paxillin expression is illustrated for two separate clones expressing the $\mathrm{EP}_{2}$ anti-sense construct (AS8 and AS9). The clonal populations were treated with vehicle or with the $\mathrm{EP}_{2}$ receptor agonist, 11-deoxy $\mathrm{PGE}_{1}(1 \mathrm{ng} / \mathrm{ml})$ for 11 days before preparation of total cell lysates. Indomethacin $(10 \mu \mathrm{g} / \mathrm{ml})$ was also added to block endogenous $\mathrm{PGE}_{2}$ production. Bottom: Membrane preparations were prepared from a duplicate set of cells treated with agonist or vehicle as described above for the top panel. $\mathrm{EP}_{2}$ receptor expression was assessed by Western blotting using the anti- $\mathrm{EP}_{2}$ receptor antibody.

threonine, and tyrosine-kinases. ${ }^{41}$ Therefore, further studies are warranted to determine whether loss of $\mathrm{EP}_{2}$ receptorcoupled cellular signaling affects the phosphorylation status of paxillin.

Finally, literature concerning prostaglandin-mediated affects on cellular physiology and pathology is full of contradictions and confounding observations. The large number of eicosanoid receptor subtypes and differential tissue expression of these receptors is likely responsible for many of these contradictory results. This study underscores the importance of examining receptor-based mechanisms to better define the role of prostaglandins in cellular behavior. Moreover, examination of receptor expression in tumors may have potential prognostic value in human malignancy.

\section{Acknowledgments}

We thank Janet Wagner and Anne Haake for their technical assistance in tissue processing and preparation of dermal equivalents.

\section{References}

1. Marks F, Furstenberger G: Cancer chemoprevention through interruption of multistage carcinogenesis. The lessons learnt by comparing mouse skin carcinogenesis and human large bowel cancer. Eur J Cancer 2000, 36:314-329

2. Asano T, Shoda J, Ueda T, Kawamoto T, Todoroki T, Shimonishi M, Tanabe T, Sugimoto Y, Ichikawa A, Mutoh M, Tanaka N, Miwa M: Expressions of cyclooxygenase-2 and prostaglandin e-receptors in carcinoma of the gallbladder: crucial role of arachidonate metabolism in tumor growth and progression. Clin Cancer Res 2002, 8:1157-1167

3. Buckman SY, Gresham A, Hale P, Hruza G, Anast J, Masferrer J, Pentland AP: COX-2 expression is induced by UVB exposure in human skin: implications for the development of skin cancer. Carcinogenesis 1998, 19:723-729

4. Fujita T, Matsui M, Takaku K, Uetake H, Ichikawa W, Taketo MM Sugihara K: Size- and invasion-dependent increase in cyclooxygenase 2 levels in human colorectal carcinomas. Cancer Res 1998 58:4823-4826

5. Gaffney DK, Holden J, Zempolich K, Murphy KJ, Dicker AP, Dodson M: Elevated COX-2 expression in cervical carcinoma: reduced cause-specific survival and pelvic control. Am J Clin Oncol 2001, 24:443-446

6. Murata H, Kawano S, Tsuji S, Tsuji M, Sawaoka H, Kimura Y, Shiozaki $\mathrm{H}$, Hori M: Cyclooxygenase-2 overexpression enhances lymphatic invasion and metastasis in human gastric carcinoma. Am J Gastroenterol 1999, 94:451-455

7. Denkert C, Kobel M, Pest S, Koch I, Berger S, Schwabe M, Siegert A, Reles A, Klosterhalfen B, Hauptmann S: Expression of cyclooxygenase 2 is an independent prognostic factor in human ovarian carcinoma. Am J Pathol 2002, 160:893-903

8. Khuri FR, Hong W, Lee JJ, Kemp BL, Lotan R, Lippman SM, Feng L, Hong WK, Xu X-C: Cyclooxygenase-2 overexpression is a marker of poor prognosis in stage I non-small cell lung cancer. Clin Cancer Res 2001, 7:861-867

9. Ristimaki A, Sivula A, Lundin J, Lundin M, Salminen T, Haglund C Joensuu $\mathrm{H}$, Isola J: Prognostic significance of elevated cyclooxygenase-2 expression in breast cancer. Cancer Res 2002, 62:632-635

10. Shirahama T, Arima J, Akiba S, Sakakura C: Relation between cyclooxygenase-2 expression and tumor invasiveness and patient survival in transitional cell carcinoma of the urinary bladder. Cancer 2001, 92:188-193

11. Pentland AP, Schoggins JW, Scott GA, Khan KN, Han R: Reduction of UV-induced skin tumors in hairless mice by selective COX-2 inhibition. Carcinogenesis 1999, 20:1939-1944

12. Fischer SM, Lo HH, Gordon GB, Seibert K, Kelloff G, Lubet RA, Conti $\mathrm{CJ}$ : Chemopreventive activity of celecoxib, a specific cyclooxygenase-2 inhibitor, and indomethacin against ultraviolet light-induced skin carcinogenesis. Mol Carcinogenesis 1999, 25:231-240

13. Prescott SM, Fitzpatrick FA: Cyclooxygenase-2 and carcinogenesis. Biochim Biophys Acta 2000, 1470:M69-M78

14. Liu CH, Chang S-H, Narko K, Trifan OC, Wu M-T, Smith E, Haudenschild C, Lane TF, Hla T: Overexpression of cyclooxygenase-2 is sufficient to induce tumorigenesis in transgenic mice. J Biol Chem 2001, 276:18563-18569

15. Subbaramaiah K, Zakim D, Weksler BB, Dannenberg AJ: Inhibition of cyclooxygenase: a novel approach to cancer prevention. Proc Soc Exp Biol Med 1997, 216:201-210

16. Breyer RM, Bagdassarian CK, Myers SA, Breyer MD: Prostanoid receptors: subtypes and signaling. Annual Rev Pharmacol Toxicol 2001, 41:661-690

17. Konger RL, Malaviya R, Pentland AP: Growth regulation of primary human keratinocytes by prostaglandin $\mathrm{E}$ receptor $\mathrm{EP}_{2}$ and $\mathrm{EP}_{3}$ subtypes. Biochim Biophys Acta 1998, 1401:221-234

18. Sonoshita M, Takaku K, Sasaki N, Sugimoto Y, Ushikubi F, Narumiya S, Oshima M, Taketo MM: Acceleration of intestinal polyposis through prostaglandin receptor $\mathrm{EP}_{2}$ in $\mathrm{APC}^{\Delta 716}$ knockout mice. Nat Med 2001, 7:1048-1051

19. Seno H, Oshima M, Ishikawa T-O, Oshima H, Takaku K, Chiba T, Narumiya S, Taketo MM: Cyclooxygenase 2- and prostaglandin $E_{2}$ receptor $\mathrm{EP}_{2}$-dependent angiogenesis in $\mathrm{APC}^{\Delta 716}$ mouse intestinal polyps. Cancer Res 2002, 62:506-511

20. Watanabe K, Kawamori T, Nakatsugi S, Ohta T, Ohuchida S, Yamamoto H, Maruyama T, Kondo K, Ushikubi F, Narumiya S, Sug- 
imura T, Wakabayashi K: Role of the prostaglandin E receptor subtype $\mathrm{EP}_{1}$ in colon carcinogenesis. Cancer Res 1999, 59:5093-5096

21. Mutoh M, Watanabe K, Kitamura T, Shoji Y, Takahashi M, Kawamori T, Tani K, Kobayashi M, Maruyama T, Kobayashi K, Ohuchida S, Sugimoto Y, Narumiya S, Sugimura T, Wakabayashi K: Involvement of prostaglandin $\mathrm{E}$ receptor subtype $\mathrm{EP}_{4}$ in colon carcinogenesis. Cancer Res 2002, 62:28-32

22. Soslow RA, Dannenberg AJ, Rush D, Woerner BM, Khan KN, Masferrer J, Koki AT: COX-2 is expressed in human pulmonary, colonic, and mammary tumors. Cancer 2000, 89:2637-2645

23. Rolland PH, Martin PM, Jacquemier J, Rolland AM, Toga M: Prostaglandin in human breast cancer: evidence suggesting that an elevated prostaglandin production is a marker of high metastatic potential for neoplastic cells. J Natl Cancer Inst 1980, 64:1061-1070

24. Hida T, Yatabe Y, Achiwa H, Muramatsu H, Kozaki K-I, Nakamura S, Ogawa M, Mitsudomi T, Sugiura T, Takahashi T: Increased expression of cyclooxygenase 2 occurs frequently in human lung cancers, specifically in adenocarcinomas. Cancer Res 1998, 58:3761-3764

25. Ohno R, Yoshinaga K, Fujita T, Hasegawa K, Iseki H, Tsunozaki H, Ichikawa W, Nihei Z, Sugihara K: Depth of invasion parallels increased cyclooxygenase-2 levels in patients with gastric carcinoma. Cancer 2001, 91:1876-1881

26. Attiga FA, Fernandez PM, Weeraratna AT, Manyak MJ, Patierno SR: Inhibitors of prostaglandin synthesis inhibit human prostate tumor cell invasiveness and reduce the release of matrix metalloproteinases. Cancer Res 2000, 60:4629-4637

27. Lala PK, Parhar RS, Singh P: Indomethacin therapy abrogates the prostaglandin-mediated suppression of natural killer activity in tumorbearing mice and prevents tumor metastasis. Cell Immunol 1986, 99:108-118

28. Kort WJ, Hulsman LO, van Schalkwijk WP, Weijma IM, Zondervan PE, Westbroek DL: Reductive effect of aspirin treatment on primary tumor growth and metastasis of implanted fibrosarcoma in rats. J Natl Cancer Inst 1986, 76:711-720

29. Connolly JM, Liu XH, Rose DP: Dietary linoleic acid-stimulated human breast cancer cell growth and metastasis in nude mice and their suppression by indomethacin, a cyclooxygenase inhibitor. Nutr Cancer 1996, 25:231-240

30. Hashimoto N, Watanabe T, Ikeda Y, Toda G, Yamada H, Yoshikawa Y, Mitsui H, Kurokawa K: Down-regulation of prostaglandin E2 receptors in regenerating rat liver and its physiological significance. Biochem Biophys Res Commun 1991, 176:226-232

31. Desai S, April H, Nwaneshiudu C, Ashby B: Comparison of agonistinduced internalization of the human $\mathrm{EP}_{2}$ and $\mathrm{EP}_{4}$ prostaglandin receptors: role of the carboxyl terminus in $\mathrm{EP}_{4}$ receptor sequestration. Mol Pharmacol 2000, 58:1279-1286

32. Zeng L, An S, Goetzl EJ: Independent down-regulation of $E P_{2}$ and $\mathrm{EP}_{3}$ subtypes of the prostaglandin $\mathrm{E}_{2}$ receptors on $\mathrm{U} 937$ human monocyte cells. Immunology 1995, 86:620-628

33. Li SR, Yang Q, Wandl E, Pirker W, Virgolini I: Acetylsalicylic acid (ASA) protects the prostaglandin-cAMP-system of human hypernephroma cells against irradiation-induced alterations. $\mathrm{Br} \mathrm{J}$ Cancer 1993, 68:695-701

34. Robertson RP, Little SA: Down-regulation of prostaglandin E receptors and homologous desensitization of isolated adipocytes. Endocrinology 1983, 113:1732-1738

35. Planchon P, Veber N, Magnien V, Israel L, Starzec AB: Alteration of prostaglandin $\mathrm{E}$ receptors in advanced breast tumour cell lines. Mol Cell Endocrinol 1995, 111:219-223

36. Abou-Issa H, Minton JP: Loss of prostaglandin E receptors during progression of rat mammary tumors from hormonal dependence to autonomy. J Natl Cancer Inst 1986, 76:101-106

37. Virgolini I, Sinzinger H, Muller C, Herman M: Human hepatocellular cancers show a decreased prostaglandin $\mathrm{E}_{1}$ binding capacity. $\mathrm{Br} \mathrm{J}$ Cancer 1989, 59:407-409

38. Newell SW, Perchellet J, Perchellet EM, Ulug ET: Alterations in focal adhesion kinase activity and associated proteins during malignant conversion of mouse keratinocytes. Mol Carcinog 1999, 25:73-83

39. Han JD, Rubin CS: Regulation of cytoskeleton organization and paxillin dephosphorylation by cAMP. Studies on murine Y1 adrenal cells. J Biol Chem 1996, 271:29211-29215

40. Salgia R, Li JL, Ewaniuk DS, Wang YB, Sattler M, Chen WC, Richards W, Pisick E, Shapiro GI, Rollins BJ, Chen LB, Griffin JD, Sugarbaker
DJ: Expression of the focal adhesion protein paxillin in lung cancer and its relation to cell motility. Oncogene 1999, 18:67-77

41. Sattler M, Pisick E, Morrison PT, Salgia R: Role of the cytoskeletal protein paxillin in oncogenesis. Crit Rev Oncog 2000, 11:63-76

42. Das K, Bohl J, Vande Pol SB: Identification of a second transforming function in bovine papillomavirus type $1 \mathrm{E} 6$ and the role of E6 interactions with paxillin, E6BP, and E6AP. J Virol 2000, 74:812-816

43. Haake AR, Cooklis M: Incomplete differentiation of fetal keratinocytes in the skin equivalent leads to the default pathway of apoptosis. Exp Cell Res 1997, 231:83-95

44. Regan JW, Bailey TJ, Pepperl DJ, Pierce KL, Bogardus AM, Donello JE, Fairbairn CE, Kedzie KM, Woodward DF, Gil DW: Cloning of a novel human prostaglandin receptor with characteristics of the pharmacologically defined $\mathrm{EP}_{2}$ subtype. Mol Pharmacol 1994, 46:213220

45. Hawtin SR, Davies ARL, Matthews G, Wheatley M: Identification of the glycosylation sites utilized on the V1a vasopressin receptor and assessment of their role in receptor signalling and expression. Biochem J 2001, 357:73-81

46. Boelsma $\mathrm{E}$, Verhoeven $\mathrm{MCH}$, Ponec M: Reconstruction of a human skin equivalent using a spontaneously transformed keratinocyte cell line (HaCaT). J Invest Dermatol 1999, 112:489-498

47. Fulton AM, Zhang SZ, Chong YC: Role of the prostaglandin $E_{2}$ receptor in mammary tumor metastasis. Cancer Res 1991, 51:20472050

48. Stillman BR, Breyer MD, Breyer RM: Importance of the extracellular domain for prostaglandin $\mathrm{EP}_{2}$ receptor function. Mol Pharmacol 1999, 56:545-551

49. Schon MP, Orfanos CE: Transformation of human keratinocytes is characterized by quantitative and qualitative alterations of the T-16 antigen (Trop-2, MOv-16). Int J Cancer 1995, 60:88-92

50. Hayes JS, Lawler OA, Walsh M-T, Kinsella BT: The prostacyclin receptor is isoprenylated: isoprenylation is required for efficient receptor-effector coupling. J Biol Chem 1999, 274:23707-23718

51. Chaturvedi V, Qin J-Z, Denning MF, Choubey D, Diaz MO, Nickoloff BJ: Apoptosis in proliferating, senescent, and immortalized keratinocytes. J Biol Chem 1999, 274:23358-23367

52. Magal SS, Jackman A, Pei XF, Schlegel R, Sherman L: Induction of apoptosis in human keratinocytes containing mutated p53 alleles and its inhibition by both the E6 and E7 oncoproteins. Int J Cancer 1998, 75:96-104

53. Donovan J, Slingerland J: Transforming growth factor- $\beta$ and breast cancer cell cycle arrest by transforming growth factor- $\beta$ and its disruption in cancer. Breast Cancer Res 2000, 2:116-124

54. Higashi Y, Kanekura T, Kanzaki T: Enhanced expression of cyclooxygenase (COX)-2 in human skin epidermal cancer cells: evidence for growth suppression by inhibiting COX-2 expression. Int J Cancer 2000, 86:667-671

55. Chen W-S, Wei S-J, Liu JM, Hsiao M, Kou-Lin J, Yang WK: Tumor invasiveness and liver metastasis of colon cancer cells correlated with cyclooxygenase-2 (COX-2) expression and inhibited by a COX2-selective inhibitor, Etorolac. Int J Cancer 2001, 91:894-899

56. Rice MG, McRae JR, Storm DR, Robertson RP: Up-regulation of hepatic prostaglandin $\mathrm{E}$ receptors in vivo induced by prostaglandin synthesis inhibitors. Am J Physiol 1981, 241:E291-E297

57. Li D, Varma DR, Chemtob S: Up-regulation of brain $\mathrm{PGE}_{2}$ and $\mathrm{PGF}_{2}$ alpha receptors and receptor-coupled second messengers by cyclooxygenase inhibition in newborn pigs. J Pharmacol Exp Ther 1995, 272:15-19

58. Weber S, Lemoine H, Wasner HK: Prostaglandin deficiency promotes sensitization of adenylyl cyclase. Biol Chem 2000, 381:525-529

59. Sales KJ, Katz AA, Davis M, Hinz S, Soeters RP, Hofmeyr MD, Millar $\mathrm{RP}$, Jabbour HN: Cyclooxygenase-2 expression and prostaglandin $E_{2}$ synthesis are up-regulated in carcinomas of the cervix: a possible autocrine/paracrine regulation of neoplastic cell function via $\mathrm{EP}_{2} / \mathrm{EP}_{4}$ receptors. J Clin Endocrinol Metab 2001, 86:2243-2249

60. Jabbour HN, Milne SA, Williams ARW, Anderson RA, Boddy SC: Expression of COX-2 and PGE synthase and synthesis of $\mathrm{PGE}_{2}$ in endometrial adenocarcinoma: a possible autocrine/paracrine regulation of neoplastic cell function via $\mathrm{EP}_{2} / \mathrm{EP}_{4}$ receptors. $\mathrm{Br} \mathrm{J}$ Cancer 2001, 85:1023-1031 
61. Fujino H, Srinivasan D, Pierce KL, Regan JW: Differential regulation of prostaglandin $\mathrm{F}_{2 \alpha}$ receptor isoforms by protein kinase C. Mol Pharmacol 2000, 57:353-358

62. Ikegami R, Sugimoto Y, Segi E, Katsuyama M, Karahashi H, Amano F, Maruyama T, Yamane H, Tsuchiya S, Ichikawa A: The expression of prostaglandin $\mathrm{E}$ receptors $\mathrm{EP}_{2}$ and $\mathrm{EP}_{4}$ and their differential regula- tion by lipopolysaccharide in $\mathrm{C} 3 \mathrm{H} / \mathrm{HeN}$ peritoneal macrophages. J Immunol 2001, 166:4689-4696

63. Giasson E, Servant MJ, Meloche S: Cyclic AMP-mediated inhibition of angiotensin II-induced protein synthesis is associated with suppression of tyrosine phosphorylation signaling in vascular smooth muscle cells. J Biol Chem 1997, 272:26879-26886 